\title{
FAKTOR-FAKTOR YANG MEMPENGARUHI MINAT PEDAGANG PASAR TRADISIONAL TERHADAP PEMBIAYAAN PADA LKMS DAN LKM
}

\section{FACTORS AFFECTING THE MOTIVATION TRADITIONAL MARKET TRADERS' INTEREST IN FINANCING AT IMFIS AND MFIs}

\author{
E. Amalia1a; M. Paramita² \\ 1aProgram Studi Ekonomi Syariah Fakultas Ekonomi Islam Universitas Djuanda Bogor, \\ Jl. Tol Ciawi No 1 Kotak Pos 35 Ciawi Bogor 16720, \\ e-mail: elzaamalia4@gmail.com \\ 2Program Studi Ekonomi Syariah Fakultas Ekonomi Islam Universitas Djuanda Bogor, Jl. \\ Tol Ciawi No 1 Kotak Pos 35 Ciawi Bogor 16720, \\ e-mail: putrikoe22@gmail.com
}

\begin{abstract}
ABSTRAK
Penelitian ini bertujuan untuk mengetahui faktor-faktor yang mempengaruhi minat pedagang pasar tradisional Jonggol terhadap pembiayaan/kredit pada LKMS dan LKM. Metode penelitian menggunakan pendekatan kuantitatif dengan teknik analisis faktor. Hasil penelitian ini menunjukan bahwa faktor-faktor yang paling dominan mempengaruhi minat pedagang dalam mengajukan pembiayaan ke LKMS yaitu faktor lokasi dan lingkungan sosial dan faktor-faktor yang paling dominan mempengaruhi minat pedagang dalam mengajukan kredit ke LKM yaitu faktor lokasi dan promosi.
\end{abstract}

Kata Kunci: LKMS, LKM, Minat, Pembiayaan / kredit

\begin{abstract}
This research aims to determine the factors that influence the interest of traditional Jonggol market traders on financing / credit to IMFIs and MFIs. The research method uses a quantitative approach with factor analysis techniques. The results of this study indicate that the most dominant factors affecting the interest of traders in applying for financing to IMFIs are location and social environment factors and the most dominant factors influence traders' interest in applying for credit to MFIs, namely location and promotion factors.
\end{abstract}

Keywords: IMFIs, MFI, Interest, Financing / credit

Amalia, E.; Paramita, M. 2020. Faktor-Faktor yang Mempengaruhi Minat Pedagang Pasar Tradisional Terhadap Pembiayaan Pada LKMS dan LKM. Jurnal Syarikah: Jurnal Ekonomi Islam 6 (1): 35 - 46. 


\section{PENDAHULUAN}

LKMS dan LKM sangat diperlukan dikalangan masyarakat untuk meningkatkan perekonomian. Keberadaannya memudahkan masyarakat menengah kebawah dalam menyimpan atau meminjam uang untuk keperluan pribadi maupun pembiayaan (Baskara, 2013). Keberadaannya memiliki tujuan yang sama yaitu untuk membantu usaha mikro kecil dan menengah serta masyarakat kecil yang keterbatasan modal untuk usaha. Hal tersebut sangat membantu bagi pemilik usaha mikro salah satunya para pedagang di pasar tradisional Jonggol yang beralamat di Jl. Jonggol-Cariu, Kecamatan Jonggol, Kabupaten Bogor dalam menambah modal untuk mengembangkan usahanya.

Minat para pedagang pasar tradisional Jonggol dalam mengajukan pembiayaan ke LKMS dan LKM didasari oleh ketertarikan para pedagang untuk menambah modal. Usahanya akan lebih berkembang dengan adanya pembiayaan yang diajukan, sehingga perekonomian para pedagang akan lebih meningkat. Dipengaruhi oleh diri sendiri, dorongan sosial yang membangkitkan untuk melakukan suatu kegiatan dan emosional yang berhubungan dengan emosi setiap individu. Menurut Anisah, dkk (2016) minat seseorang timbul karena pengaruh dua faktor yaitu:

1. Faktor Internal, merupakan faktor dasar yang alami timbul pada diri sendiri bukan karena pengaruh sosial.

2. Faktor Eksternal, pengaruh dari orang lain untuk melaksanakan suatu aktivitas.

Para pedagang memerlukan pertimbangan untuk memilih lembaga keuangan mikro karena setiap pedagang memiliki penilaian yang berbeda mengenai lembaga keuangan mirko berbasis syariah dan konvensional. Para pedagang pasar tradisional Jonggol mengajukan pembiayaan ke lembaga yang mudah dijangkau dan prosedurnya mudah sehingga pembiayaan yang diajukan cepat dicairkan oleh pihak lembaga keuangan untuk mempercepat para pedagang dalam mengembangkan usahanya. Responden beranggapan lembaga keuangan mikro lebih mudah untuk mencairkan pembiayaan bagi para pedagang.

Faktor lain yang menjadi pertimbangan para pedagang yaitu lokasi atau jarak yang ditempuh, lingkungan sosial dan promosi. Pedagang akan memilih yang aksesnya mudah untuk menuju lokasi lembaga keuangan mikro, karena lebih mempermudah pedagang. Lingkungan sosial seperti lingkungan masyarakat sangat mempengaruhi pedagang. Interaksi antara pedagang dengan masyarakat dilingkungannya akan menjadi pertimbangan pedagang karena manusia memiliki sifat mencontoh dan mencoba hal-hal yang baru. Promosi yang dilakukan mempengaruhi pedagang yang akan mengajukan pembiayaan atau kredit.

\section{MATERI DAN METODE}

\section{Minat}

Crowdan Crow menyatakan dalam Djaali (2013:121) bahwa minat berkaitan dengan gerak seseorang yang mendorong untuk melakukan suatu kegiatan atau pengalaman dirangsang oleh apa yang telah dilakukan. Menurut Prof. Dr. Iskandarwasid dan Dr. H. Dadang 
Sunendar (2011) minat adalah gabungan antara kemauan seseorang dan keinginannya yang berkembang.

Terdapat tiga batasan minat yaitu pertama, suatu sikap atau persepsi seseorang yang dapat mengikat perhatian ke arah objek tertentu. Kedua, perasaan suatu aktivitas atau kegemaran terhadap suatu objek tertentu sangat berharga. Ketiga, sebagai motivasi yang membawa tingkah laku ke tujuan tertentu. Berdasarkan pengertian diatas disimpulkan bahwa minat adalah keterkaitan antara pribadi seseorang dengan hal yang disenangi, disukai dan diminati yang menjadi sumber motivasi dan terus diperhatikan. Perhatian terhadap suatu halakan melahirkan minat dengan informasi dan pengatahuan yang dimiliki, sehingga terjadinya perubahan sikap seseorang.

\section{Lembaga Keuangan Mikro Syariah (LKMS)}

LKMS memiliki kegiatan mengembangkan usaha agar lebih produktif dengan mendorong untuk menabung dan menyalurkan pembiayaan kegiatan ekonomi anggota serta masyarakat di lingkungannya (Muttaqien, 2010). Berikut hadist sebagai landasan berbagai kegiatan keuangan di lembaga keuangan mikro syariah:

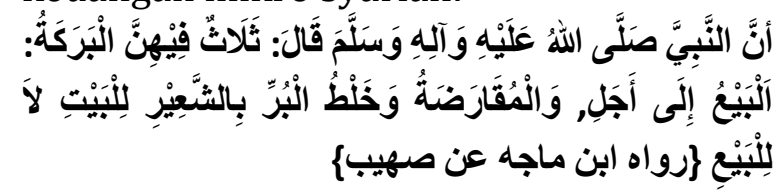

"Nabi saw. bersabda, ada tiga hal yang mengandung berkah: jual beli tidak secara tunai, muqaradhah (mudharabah), dan mencampur gandum dengan jewawut untuk keperluan rumah tangga, buka untuk dijual."
Menurut Ais Zakiyudin (2017:36) jenis-jenis LKMS terdiri dari beberapa lembaga yaitu:

a. Bank Perkreditan Rakyat Syariah, (BPRS) merupakan bank yang sistem transaksinya menggunakan sistem syariah dalam operasionalnya. Bentuk badan hukum dari BPRS dapat berupa Perseroan Terbatas, Perusahaan Daerah dan Koperasi.

b. Baitul Maal wa Tamwil (BMT), kegiatan utamanya mendistribusikan dan menghimpun dana zakat, infaq, shadaqoh, wakaf dan hibah tanpa mengharapkan keuntungan. Operasionalnya memperhitungkan keuntungan, kegiatan utamanya adalah mengumpulkan dana dan menyalurkan kepada anggota yang sesuai sistem syariah.

c. KJKS, mendukung perkembangan usaha berdasarkan sistem syariah. Menggunakan akad-akad syariah dalam bertransaksi, serta menjalin kerjasama dengan masyarakat.

d. Pegadaian Syariah, menyediakan jasa sesuai prinsip syariah. Barang yang ditahan dalam gadai syariah dan yang menahan memiliki jaminan mengambil sebagian atau seluruh piutangnya.

e. Asuransi Syariah, merupakan lembaga yang bertujuan tolong menolong (ta'awun) dan saling melindungi (takaful)diantara para peserta melalui dana tabarru yang dikelola sesuai syariah untuk meminimalisir resiko tertentu. Peserta asuransi akan menghibahkan kontribusinya untuk membayar klaim peserta lain karena mendapat musibah. Pihak perusahaan asuransi syariah hanya berperan sebagai pengelola investasi dan 
operasional dari jumlah dana yang terkumpul.

\section{Lembaga Keuangan Mikro (LKM)}

Menurut Undang-Undang Nomor 1 Tahun 2013 LKM adalah lembaga keuangan yang didirikan untuk pemberdayaan masyarakat kecil dalam mengembangkan usaha skala mikro melalui pinjaman atau pembiayaan. Keberadaannya dianggap berhasil oleh masyarakat menjadi lembaga intermediasi dalam aktivitas perekonomian yang tidak terjangkau pelayanan jasa perbankan umum atau konvensional. Lembaga keuangan mikro sebagai lembaga yang menyediakan jasa penyimpanan bagi masyarakat yang menabung, kredit, pembayaran untuk transaksi jasa serta sistem transfer (Handayani, 2015).

Menurut Ihwan Susila (2017) jenisjenis LKM terdiri dari beberapa lembaga yaitu:

a. Bank Perkreditan Rakyat (BPR), lembaga yang melaksanakan kegiatan secara konvensional dan lebih sempit, menerima simpanan hanya deposito berjangka.

b. Koperasi Simpan untuk menyimpan dana para anggota yang nantinya akan dipinjamkan kembali kepada anggota lain yang membutuhkan dengan bunga ringan. Hal tersebut dilakukan untuk kesejahteraan anggotanya.

c. Pegadaian, pinjaman uang dengan cara menggadaikan barang milik nasabah untuk jaminannya. Setiap peminjaman memiliki jangka waktu, jika tidak dilunasi maka barang jaminan nasabah hangus.

d. Asuransi, merupakan asuransi sesuai akad jual beli atau investasi dana bebas menggunakan prinsip tertentu. Dana yang terkumpul adalah hak perusahaan untuk dikelola untuk usaha yang mungkin melanggar hukum syariah.

\section{Metodologi Penelitian}

Penelitian ini menggunakan data yang terdiri dari primer dan sumber. Menurut Suharismi Arikunto (2013:172) data primer adalah pokok yang diolah sendiri oleh peneliti langsung dari objek penelitian. Data pokok yaitu data yang diperoleh dari orang pertama atau subjek penelitian

Pengumpulannya menggunakan metode wawancara dan kuesioner (angket). Sedangkan data sekunder diperoleh dengan membaca, memahami dan mempelajari melalui media yang bersumber dari literatur seperti buku atau doukumen (Sugiyono 2015).

Dalam mengumpulkan data digunakan metode sebagai berikut:

1. Wawancara, merupakan percakapan dengan waktu tertentu. Dilakukan oleh peneliti yang memberikan pertanyaan dan narasumber yang menjawab pertanyaan (Moleong, 2008:186). Jenis wawancaranya tidak terstruktur atau pembicaraan informal. Pedoman yang digunakan berupa garis besar permasalahan, wawancara akan dilakukan kepada salah satu pedagang.

2. Kuesioner (angket), merupakan alat pengumpulan data berupa teks pertanyaan yang diajukan kepada responden. Jenis angketnya yaitu angket langsung, diberikan langsung kepada responden yang akan diteliti. Jawabannya diperoleh dari orang pertama. Menggunakan angket berstruktur dengan pertanyaan terbatas. Penghitungannya digunakan skala likert, yaitu skala pengukuran 
sikap responden terhadap sesuatu. Untuk penilaian pada tiap jawaban yang diberikan oleh responden.

Setelah memperoleh data yang diperoleh dari penyebaran kuesioner, selanjutnya dilakukan uji reliabilitas dan validitas. Uji reliabilitas dilakukan pada kuesioner dan diolah dengan aplikasi SPSS dari masing-masing instrumen pengukuran menggunakan uji cronbach alpha. Kuesioner dikatakan reliabilitas apabila nilai koefisien alpha lebih besar dari 0,60 ( $a>0,60)$. Sedangkan Uji validitas adalah suatu langkah pengujian terhadap suatu instrumen. Kevalidan instrumen berarti dapat digunakan untuk mengukur data (Sugiyono, 2010).

Teknik analisis data menggunakan analisis faktor yang didefinisikan sebagai analisis multivariat yang memiliki 41 fungsi untuk menentukan satu atau beberapa variabel. Metode analisis faktor juga disebut suatu analisa data untuk mengetahui faktor-faktor yang dominan dalam menjelaskan suatu masalah.

\section{HASIL DAN PEMBAHASAN}

\section{Analisis Deskriptif Responden}

Menyebar 22 kuesioner untuk responden yang mengajukan pembiayaan ke LKMS dan 28 untuk responden LKM. Sebanyak 14 responden perempuan dan 8 laki-laki (LKMS). 19 responden perempuan dan 9 laki-laki (LKM). Usia responden lembaga keuangan mikro syariah yaitu sebanyak 9 dengan usia 3040 tahun, 8 responden usia 40-50 tahun dan 5 dengan usia $>50$ tahun. Untuk LKM yaitu sebanyak 12 berusia 30-40 tahun, 10 usia 40-50 tahun dan 6 responden usia $>50$ tahun. Sehingga dari hasil penelitian ini berdasarkan usia responden menyatakan bahwa yang paling dominan yaitu berusia 30-40 tahun.

Pendidikan terakhir SD/MI sebanyak 10, SMP sebanyak 7 dan SMA 5 responden untuk LKMS. SD/MI sebanyak 14 responden, SMP sebanyak 8 dan SMA sebanyak 6 responden untuk LKM. Sehingga hasil penelitian ini menyatakan bahwa mayoritas responden berpendidikan SD/MI. Penghasilan responden lembaga keuangan mikro syariah sebanyak 3 responden dengan penghasilan 10-20 juta, 3 berpenghasilan 20-30 juta, 8 dengan penghasilan 30-40 juta, 6 responden dengan penghasilan 4050 juta dan 2 berpenghasilan $>50$ juta. Responden lembaga keuangan mikro konvensional yaitu 2 dengan penghasilan 10-20 juta, 5 berpenghasilan 20-30 juta, 10 responden berpenghasilan 30-40 juta, 8 dengan penghasilan 40-50 juta dan 3 berpenghasilan $>50$ juta.

Jenis usaha responden LKMS 2 pedagang perabot, 1 pedagang obatobatan, 3 pedagang sembako, 4 pedagang ikan asin, 3 pedagang pakaian dan 9 pedagang sayuran. Untuk responden LKM yaitu 3 pedagang perabot, 3 pedagang warteg, 4 pedagang sembako, 5 pedagang ikan asin, 4 pedagang pakaian dan 9 pedagang sayuran.

\section{Uji Kaiser Mayor Olkin (KMO)}

Angka KMO mencapai 0,647 untuk responden yang mengajukan pembiayaan ke LKM. Hal ini termasuk hasil katagori baik mengingat angka KMO-MSA telah melebihi batas nilai KMO yaitu 0,50. Adapun nilai Bartlett's Test of Sphericity mempunyai nilai 21,987 dengan nilai signifikansi 0,002 untuk responden yang mengajukan pembiayaan ke LKMS dan 22,226 dengan nilai signifikan 0,001 untuk responden yang mengajukan 
pembiayaan ke LKM. Nilai ini berarti pembentuk variabel sudah baik serta boleh dianalisis ke tahap selanjutnya.

\section{Proses Ekstraksi}

Inti dari analisis faktor yaitu proses ekstraksi pada sekumpulan variabel yang sudah lulus dalam uji validitas sebelumnya, sehingga akan membentuk satu hingga lebih faktor. Pada proses ekstraksi faktor ini menggunakan IBM SPSS 22 dengan motode ekstraksi principal component analysis (PCA) dengan tingkat eigenvalues over $=1$, yang artinya item angka dengan angka eigenvalues < 1 akan dikeluarkan. Komunalitas merupakan proporsi varian variabel yang dapat dipaparkan oleh faktor.

Nilai intial menggambarkan estimasi varian masing-masing variabel berdasarkan faktor yang terbentuk. Semua nilai intial bernilai 1, hal ini berarti varian variabel dapat didefinisikan pada faktor yang telah terbentuk. Nilai komunalitas extraction menggambarkan seberapa besar presentase variabel yang dapat digambarkan oleh faktor yang terbentuk. Hasil penelitian responden yang mengajukan pembiayaan ke LKMS menunjukan bahwa variabel yang memiliki nilai extraction tertinggi adalah variabel lingkungan sosial sebesar 0,766. Hal ini berarti 76,6\% varian variabel akan terbentuk. Variabel persepsi sebesar 0,723, variabel lokasi sebesar 0,758 dan variabel promosi sebesar 0,654.

Hasil penelitian responden yang mengajukan pembiayaan ke LKM menunjukan bahwa variabel yang memiliki nilai extraction tertinggi adalah variabel lingkungan sosial sebesar 0,792. Hal ini berarti 79,2\% varian variabel akan terbentuk. Variabel persepsi sebesar
0,695, variabel lokasi sebesar 0,782 dan variabel promosi sebesar 0,742 . Semakin besar nilai communalities suatu variabel, maka semakin kuat hubungan dengan faktor yang nantinya akan terbentuk.

Selanjutnya

berdasarkan pengolahan data dengan SPSS 22 didapat hasil bahwa 4 variabel akan dikelompokan menjadi 2 faktor yaitu untuk responden yang mengajukan pembiayaan ke LKMS memiliki variabel yang termasuk dalam component 1 yaitu lokasi $(0,865)$ dan lingkungan sosial $(0,871)$. Hasil ini dinyatakan bahwa variabel tersebut mempunyai korelasi yang tinggi terhadap faktor 1 . Kemudian untuk component 2 yaitu persepsi $(0,850)$ dan lokasi $(0,783)$. Hasil analisis faktor dengan 4 variabel yang diteliti menggunakan metode ekstraksi principle component analysis yang direduksi menjadi 2 faktor dimana lokasi dan lingkungan sosial menjadi faktor 1 , sedangkan persepsi dan promosi menjadi faktor 2 .

Responden yang mengajukan pembiayaan ke LKM memiliki variabel yang termasuk dalam component 1 yaitu lingkungan sosial $(0,849)$ dan promosi $(0,888)$. Hasil ini dinyatakan bahwa variabel tersebut mempunyai korelasi yang tinggi terhadap faktor 1 . Kemudian untuk component 2 yaitu persepsi $(0,791)$ dan lokasi $(0,884)$. Hasil analisis faktor dengan 4 variabel yang diteliti menggunakan metode ekstraksi principle component analysis yang direduksi menjadi 2 faktor dimana lingkungan sosial dan promosi menjadi faktor 1 , sedangkan persepsi dan lokasi menjadi faktor 2 .

\section{Penamaan Faktor}


Berdasarkan hasil penelitian dari analisis faktor yang telah dijelaskan, dapat di uraikan sebagai berikut:

1. Faktor-Faktor yang Mempengaruhi Pedagang Pasar Tradisional Mengajukan Pembiayaan ke LKMS

Hasil analisis data menggunakan analisis faktor menunjukkan terdapat dua faktor yang mendukung atas pedagang pasar tradisional mengajukan pembiayaan ke LKMS. Adapun faktorfaktor pertama merupakan faktor paling dominan atau mempengaruhi pedagang pasar tradisional Jonggol dalam mengajukan pembiayaan ke LKMS. Faktor pertama dinamakan faktor "Sosial" yaitu aktivitas yang dilakukan oleh individu yang dipengaruhi oleh lingkungan luar untuk mencapai sasarannya (Yuriska, 2014). Maka persamaan matematis untuk faktor sosial yaitu:

\section{Faktor Sosial $=\quad 0,865$ Lokasi $+\mathbf{0 , 8 7 1}$ Lingkungan Sosial}

Faktor sosial ini memiliki nilai eigenvalue sebesar 1,776, merupakan faktor yang paling mempengaruhi minat pedagang pasar tradisional Jonggol dalam mengajukan pembiayaan ke LKMS. Menerangkan keragaman data sebesar 44,407 persen.

Pemilihan lokasi yang strategis untuk suatu lembaga akan lebih unggul dengan lokasi yang kurang strategis (Fure, 2013:274). Setiap perusahaan membutuhkan lokasi yang strategis untuk menarik minat pengunjungnya (Suryani, 2015). Lokasi LKMS berperan penting dalam meningkatkan minat responden untuk mengajukan pembiayaan. Jarak antara pasar ke LKMS memang tidak terlalu dekat yaitu perjalanan selama 45 menit, namun medan yang harus ditempuh cukup baik dan bebas dari hambatan sehingga sebagian masyarakat mengajukan pembiayaan. Dari hasil wawancara menunjukan bahwa bagi responden yang mengajukan pembiayaan, lokasi LKMS menjadi faktor utama bukan karena jarak antara pasar ke LKMS tetapi karena perjalanan yang bebas hambatan dan keberadaan LKMS di tempat yang strategis.

Lingkungan sosial merupakan wadah masyarakat dan memiliki hubungan dengan kehidupan sehari-hari (Yuliyatun, 2012). Interaksi yang teradi antara responden dengan lingkungan sekitar akan menghasilkan informasi yang dapat membantu responden. Informasi-informasi tersebut dapat mempengaruhi minat responden dalam mengajukan pembiayaan ke LKMS.

Faktor lingkungan sosial mempengaruhi karena ada sebagian pedagang yang sudah mengajukan pembiayaan ke LKMS dan mayoritas pedagangnya yaitu bapak haji/ibu hajjah, informasi yang didapat dari pedagang tersebut mempengaruhi pedagang yang lain untuk mengajukan pembiayaan ke LKMS. Dari hasil wawancara responden berminat mengajukan pembiayaan ke LKMS dipengaruhi lingkungan sosial yaitu pedagang yang mengajukan pembiayaan ke LKMS yang lebih mengetahui bagaimana mekanisme pembiayaan tersebut dan salah satu responden berminat mengajukan pembiayaan ke LKMS karena ada tetangganya yang bekerja di LKMS.

Faktor-faktor kedua dinamakan faktor "Produk Influance" karena berkaitan dengan usaha-usaha yang dilakukan oleh perusahan untuk meningkatkan awareness nasabah terhadap suatu produk dengan 
menumbuhkan loyalitas tinggi dan membangun sebuah ingatan para nasabah sehingga terciptanya persepsi yang baik tentang pembiayaan di LKMS (Hardiyani, 2018). Maka persamaan matematis untuk faktor produk influance yaitu:

\section{Faktor Produk Influance $=\quad \mathbf{0 , 8 5 0}$ Persepsi + 0,783 Promosi}

Faktor produk influance ini memiliki nilai eigenvalue sebesar 1,125, merupakan faktor pendukung yang mempengaruhi minat pedagang pasar tradisional Jonggol dalam mengajukan kredit ke LKM.

Persepsi merupakan kecenderungan seseorang terhadap suatu hal dalam ranah relatif (Nugraha, 2015). Persepsi diartikan sebagai penilaian seseorang terhadap suatu hal, artinya persepsi setiap individu berbeda-beda seperti responden yang memiliki persepsi berbeda-beda mengenai pembiayaan di LKMS, penilaian responden mengenai LKMS ada yang positif dan negatif. Hal tersebut yang menyebabkan perbedaan minat diantara responden. Penilaian yang positif akan meningkatkan minat responden dalam mengajukan pembiayaan, sedangkan penilaian negatif akan menjadi pertimbangan bagi responden. Dari hasil wawancara sebagian responden kurang memahami mengenai LKMS dan mekanisme pembiayaan di LKMS sehingga faktor persepsi menjadi faktor pendukung.

$$
\text { Promosi adalah kegiatan }
$$

memberitahukan keunggulan produk yang dimiliki perusahaan dan promosi sangatlah penting agar tujuan perusahaan tercapai (Ariyanti, 2014:4). Artinya promosi penting dilakukan untuk menarik minat responden dalam mengajukan pembiayaan dan memudahkan responden untuk mengetahui produk di LKMS. Pomosi dapat dilakukan dengan berbagai cara seperti mendatangi langsung dan melalui media elektronik yang mudah dilihat banyak orang. Dari hasil wawancara menunjukan bahwa promosi yang dilakukan LKMS belum terlalu intens sehingga hanya sebagian responden yang berminat mengajukan pembiayaan ke LKMS.

2. Faktor-Faktor yang Mempengaruhi Pedagang Pasar Tradisional Mengajukan Pembiayaan ke LKM

Analisis data atas faktor-faktor pedagang pasar tradisional mengajukan pembiayaan ke LKM menunjukkan bahwa terdapat dua faktor yang mendukung yaitu faktor pertama sebagai factor utama dan faktor kedua sebagai faktor pendukung. Faktor-faktor pertama ini dinamakan faktor "Produk Influance" yang dipengaruhi oleh usaha-usaha perusahaan untuk meningkatkan keyakinan dan loyalitas masyarakat untuk mengajukan pembiayaan ke LKMS, seperti promosi yang dilakukan akan meningkatkan minat lingkungan masyarakat terhadap suatu produk. Maka persamaan matematis untuk faktor produk influance yaitu:

Faktor Produk Influance $=\quad \mathbf{0 , 8 4 9}$ Lingkungan Sosial + 0,888 Promosi

Faktor produk influance ini memiliki nilai eigenvalue sebesar 1,862 , merupakan faktor yang paling mempengaruhi minat pedagang pasar tradisional Jonggol dalam mengajukan kredit ke LKM.

Lingkungan sosial merupakan adalah seluruh aspek yang ada disekeliling kita, dalam arti spesifik 
lingkungan merupakan hal yang mempengaruhi perkembangan manusia (Parjiyono, 2008). Berpengaruh artinya bermakna, berfungsi dan berperan terhadap keputusan pedagang pasar tradisional Jonggol dalam mengajukan kredit ke LKM.

Lingkungan sosial meliputi semua kondisi yang ada disekitar dan mempengaruhi tingkah laku, perkembangan dan pertumbuhan seseorang (Tamara, 2016). Lingkungan sosial menjadi faktor utama dilihat dari hasil wawancara yang menunjukan bahwa lingkungan masyarakat di daerah Jonggol memiliki kebiasaan meminjam uang kepada rentenir atau ke lembaga yang berbasis konvensional karena minimnya pemahaman mengenai lembaga keuangan berbasis syariah, sehigga hal tersebut berpengaruh terhadap minat responden dalam mengajukan kredit ke LKM.

Promosi adalah kegiatan untuk menjelaskan manfaat keunggulan suatu produk untuk mempengaruhi agar membeli produk atau penggunaan jasa yang sesuai dibutuhkan (Lupiyoadi, 2013). Marketing lembaga keuangan harus mempromosikan produk-produk yang ada di lembaga keungan secara maksimal. Hal tersebut akan berpengaruh terhadap minat pedagang pasar tradisional Jonggol dalam mengajukan kredit ke LKM.

Tujuan promosi yang dilakukan diantaranya yaitu untuk menyebar luaskan informasi kepada calon nasbah, untuk mendapatkan nasbah yang baru dan membentuk citra produk dan lembaga keuangan dikalangan pedagang pasar tradisional Jonggol. Dari hasil wawancara responden berminat mengajukan kredit ke LKM karena marketing LKM mendatangi langsung untuk menawarkan dan menjelaskan produk-produk yang ada di LKM sehingga faktor promosi menjadi faktor utama yang mempengaruhi responden dalam mengajukan kredit ke LKM.

Faktor-faktor kedua dinamakan faktor "Personal Influance" karena berpengaruh lebih yang bersifat personal decision atau mempengaruhi keputusan suatu individu karena sebuah referensi personal terhadap suatu aspek (Yuriska, 2014). Maka persamaan matematis untuk faktor personal influance yaitu:

\section{Faktor Personal Influance $=\quad 0,791$ Persepsi + 0,884 Lokasi}

Faktor personal influance ini memiliki nilai eigenvalue sebesar 1,149, merupakan faktor pendukung yang mempengaruhi minat pedagang pasar tradisional Jonggol dalam mengajukan kredit ke LKM.

Persepsi adalah proses dalam memahami rangsangan dari lingkungan yang didengar, dilihat dan dirasa (Thohah, 1996 dalam Anwar, Najib \& Mursidah, 2011:44). Munculnya hal tersebut tergantung bagaimana cara seseorang menggambarkan informasi yang didapat dari pola pikir seseorang. (Irwanto,2002:71).

Pengetahuan pedagang pasar tradisional Jonggol mengenai kredit di LKM akan mempengaruhi minat responden dalam mengajukan kredit. Pengetahuan tersebut didapatkan dari masyarakat sekitar, anggota keluarga maupun langsung dari pihak lembaga keuangan. Hal tersebut yang akan menjadi acuan pedagang pasar tradisional dalam menentukan keputusannya untuk mengajukan kredit. 
Dari hasil wawancara menunjukan bahwa responden berminat mengajukan kredit ke LKM bukan karena penilaian pribadi responden saja, namun dipengaruhi juga oleh informasi atau dorongan dari orang lain yang menarik minat responden dalam mengajukan kredit ke LKM, sehingga faktor persepsi menjadi faktor pendukung bagi responden.

Lokasi merupakan tempat pelayanan yang berhubungan dengan suatu tempat dan melakukan kegiatan sesuai aturannya (Hurriyati, 2015). Lokasi memiliki peran penting dalam perusahaan karena menentukan banyaknya konsumen yang berkunjung, jika lokasi perusahaan mudah dijangkau maka akan banyak yang berkunjung. Responden dalam penelitian ini juga memperhatikan lokasi LKM yang mudah dijangkau lebih diminati responden karena memudahkan ketika mengunjunginya. Dari hasil wawancara lokasi antara pasar ke LKM lebih dekat dibandingkan ke LKMS, namun sebagian responden untuk mengajukan pembiayaan ke LKMS. Sehingga lokasi merupakan faktor pendukung karena tidak semua responden mengajukan ke LKM walaupun lokasinya lebih dekat.

\section{KESIMPULAN DAN IMPLIKASI}

$\begin{array}{clr}\text { Setelah } & \text { melakukan } & \text { penelitian } \\ \text { mengenai } & \text { faktor-faktor } & \text { yang }\end{array}$
mempengaruhi minat pedagang pasar tradisional Jonggol terhadap pembiayaan pada LKMS dan LKM, terdapat beberapa kesimpulan yaitu:

1. Faktor lokasi atau jarak yang sangat mempengaruhi responden dalam memilih lembaga keuangan. Sebelum mengajukan pembiayaan responden memperhatikan lokasi lembaga keuangan yang akan dikunjungi, jarak yang lebih dekat antara lembaga keuangan ke pasar tradisional Jonggol akan lebih diminati responden.

2. Faktor yang mempengaruhi persepsi pedagang pasar tradisional Jonggol dalam mengajukan pembiayaan ke LKMS adalah faktor persepsi $(0,850)$, lokasi (0,865), lingkungan sosial (0.871) dan promosi $(0,785)$ dan faktor yang mempengaruhi persepsi pedagang pasar tradisional Jonggol dalam mengajukan kredit ke LKM adalah faktor persepsi $(0,791)$, lokasi $(0,884)$, lingkungan sosial $(0.849)$ dan promosi $(0,888)$. Faktor paling dominan mempengaruhi pada LKMS yaitu faktor lokasi dan lingkungan sosial karena pada tabel Rotated Component Matrix termasuk kedalam faktor 1 atau faktor utama, sedangkan faktor yang paling dominan pada LKM yaitu faktor lokasi dan promosi dilihat pada tabel Rotated Component Matrix termasuk kedalam faktor 1 atau faktor utama.

Adapun implikasi yang dapat disampaikan setelah melakukan penelitian pada pedagang pasar tradisional Jonggol yaitu:

1. Perlu adanya dukungan pemerintah untuk mengadakan sosialisasi mengenai lembaga keuangan berskala mikro, karena pemahaman sebagian responden belum maksimal disebabkan kebiasaan mereka yang meminjam uang ke rentenir.

2. Untuk penelitian selanjutnya, jika dengan tema atau konsep yang sama maupun tidak sampai hanya mengetahui faktor dominannya saja namun bisa dilanjutkan dengan 
menghitung preferensinya, dan dapat ditambahkan dengan variabel yang belum ada pada penelitian ini, seperti variabel faktor ekonomis untuk hasil penelitian yang variatif mengenai preferensi terhadap LKMS dan LKM.

\section{DAFTAR PUSTAKA}

Anisah, Fajri, Widyawati. (2016). Analisis Faktor-Faktor yang Mempengaruhi Mahasiswa Agribisnis Dalam Berkoperasi Pada Fakultas Pertanian Universitas Syariah Kuala. Jurnal Imliah Pertanian Unsyiah. Vol. 1, No. 1. November 2016.

Anwar, Kaspul. Najib. M \& Mursidah. (2011). Persepsi Dan Reaksi Masyarakat Terhadap Keberadaan Koperasi Unit Desa (KUD) Serba Usaha Di Desa Kalinjanulu Kecamatan Muaro Ancalong Kabupaten Kutai Timur.EPP. Vol 08 No 012011 Hal 44-46.

Arikunto, S. (2013). Prosedur Penelitian Suatu Pendekatan Praktik. Jakarta: Rineka Cipta.

Ariyanti, T. (2014). Pengaruh Strategi Promosi Terhadap Penjualan Produk di PT. UNITED INDO Surabaya. Jurnal Ilmu dan Riset Manajemen. Vol. 3 No. 10, 1-19.

Baskara, I.Gde.Kanjeng. (2013). Lembaga Keuangan Mikro di Indonesia. Jurnal Buletin Studi Ekonomi. Vol. 18, No.2.

Djaali. (2011). Psikologi Pedidikan. Jakarta: BumiAksara.

Fure, H. (2013). Lokasi, Keberagaman Produk, Harga dan Kualitas Pelayanan Pengaruhnya Terhadap Minat Beli Pada Pasar Tradisional
Bersehati Calaca. Jurnal EMBA.Vol. 1 No. 3, 273-283.

Handayani. (2015). Strategi Penanganan Pembiayaan Bermasalah Pada Produk Pembiayaan Mudharabah Di KJKS Mitra Sejahtera.Skripsi: Universitas Negeri Islam Wali Songo Semarang.

Hurriyati, R,. (2015). Bauran Pemasaran dan Loyalitas Konsumen. Bandung: ALFABETHA.

Ihwan Susila. (2017). Analisis Efisiensi Lembaga Keuangan Mikro. Jurnal Ekonomi Pembangunan. Vol. 8, No. 2. Irwanto.(2002). Psikologi Umum Buku Panduan

Mahasiswa.Jakarta:Prehallindo.

Kasiram. (2008). Metodologi Penelitian. Malang: UIN-Malang Pers.

Lupiyoadi, R, (2013). Manajemen Pemasaran Jasa Berbasis Kompetensi (Edisi 3). Jakarta: Salemba Empat.

Muttaqien, D. (2010). Urgensi Legalitas Lembaga Keuangan Mikro Syariah.Skripsi: Universitas Islam Indonesia.

Moleong J, Lexy. (2008). Metodologi Penelitian Kualitatif. Bandung: Pt Remaja Rosdakarya.

Nugraha, U. (2015). Hubungan Persepsi, Sikap dan Motivasi Belajar Terhadap Hasil Belajar Pada Mahasiswa Pendidikan Olahraga dan Kesehatan. Skripsi: Universitas Jambi.

Sugiyono. (2015). Metode Penelitian dan Pengembangan. Research and Develoment.

Sugiyono. (2010).Metode Penelitian Kuantitatif Kualitatif dan R\&D.Bandung: Alfabeta.

Suryani, Y. (2015). Teori Lokasi Dalam Penentuan Pembangunan 
LokasinPasar Tradisional. Skripsi: Unand Limau Manis Padang.

Tamara, M.. (2016). Peranan Lingkungan Sosial Terhadap Pembentukan Sikap Peduli Lingkungan Peserta Didik. Jurnal Pendidikan. Vol. 16, No. 1. Undang-Undang Nomor 1 Tahun 2013 tentang Lembaga Keuangan Mikro (LKM).

Wasid Iskandar, Sunendar D. (2011).

Strategi Pembelajaran Bahasa.

Bandung: Rosda, Cet. Ke-3, 2011.

Yuliyatun. (2012). Pengaruh Lingkungan

Sosial dan Motivasi Belajar
Terhadap Prestasi Belajar Ekonomi. Skripsi: Universitas Muhammadiyah Surakarta.

Zakiyudin Ais. (2017). Lembaga Keuangan Mikro Syariah Sebagai Solusi Alternatif Pemberdayaan Usaha Mikro. Simposium Nasional Ilmu Pengetahuan dan Teknologi (SIMNASIPTEK) 2017. 